\title{
Parking Application Using Dual-Layered Geofencing (Circle and Polygon) and Activity Recognition (Case Study: UIN Syarif Hidayatullah Jakarta)
}

\author{
$1^{\text {st }}$ Muhammad Alvin Syahrin ${ }^{1}, 2^{\text {nd }}$ Arini $^{1}, 3^{\text {rd }}$ Husni Teja Sukmana ${ }^{1}, 4^{\text {th }}$ Anggraeni Endah \\ Kusumaningrum ${ }^{2}, 5^{\text {th }}$ Hervina Puspitosari $^{2}$ \\ \{muhammad.syahrin14@mhs.uinjkt.ac.id ${ }^{1}$, arini@uinjkt.ac.id ${ }^{1}$, husniteja@uinjkt.ac.id ${ }^{1}$, \\ anggraeniwijayanto@yahoo.ac.id ${ }^{2}$, hervina@unsa.ac.id ${ }^{2}$ \}
}

UIN Syarif Hidayatullah, Department of Informatics Engineering, Jakarta, Indonesia ${ }^{1}$, University of Surakarta, Faculty of Law, Indonesia ${ }^{2}$

\begin{abstract}
The information of available parking lot in UIN Syarif Hidayatullah is not provided. It becomes a problem because when the rider wants to park his vehicle but does not know which parking area is still available then the driver will waste his time by searching for available parking even though not necessarily he will find it. The purpose of this research is to develop the application that can solves the problem so that students or other campus residents can easily find available parking. The application design uses dual-layered geofencing and activity recognition to identify the user's parking activities without the use of sensors in every parking area. The results of this study is an application parking management android-based with a server that uses PHP programming language and MySQL database. Detected parking success was $70 \%$ with the average distance required for detection was 8,71 meters.
\end{abstract}

Keywords: parking, geofencing, activity recognition, android

\section{Introduction}

One of the most widely used transportation today is motor vehicles. Motor vehicles become one of the important factors supporting human mobilization and logistics of human needs goods itself. Thus, motor vehicles are able to influence economic development in an area.

Every year the number of motor vehicles continues to increase [1]. Although it has many benefits for human life, the increasing in the number of vehicles will cause problems. And the problems that can be caused by the increasing number of motor vehicles are air pollution, traffic jam, and difficulty of finding parking space.

Problems that occurred in UIN Syarif Hidayatullah result from the increase of motor vehicles is the difficulty of finding parking space. Although there are already some parking areas, there are still drivers who park their vehicles in any place. In addition, the existing parking management system has not been able to provide information of parking area availability directly to the driver so that the driver has difficulty and takes more time to just look for the parking space. 
In this journal, geofencing and activity recognition is used to detect driver who park their vehicles through their smartphones. Geofencing used in this study will combine the circle geofence and polygon geofence. Circle form as the area where the user will get the parking information and the polygon form signifies the parking area where the system will reduce the parking slot when there are users who parked in the area.

Geofencing is a virtual boundary or geographical or virtual perimeter line around a point with a pre-defined set of boundaries in a mapped geographical area either using a GPS (Global Positioning System) or RFID (Radio Frequency Identification) or beacons or other technology [2]. This research uses Geofencing API from Google.

And the activity recognition used in this research is Activity Recognition API which is also from Google. Activity Recognition API is one of the features of Location API owned by Google Play Service. The Activity Recognition API can tell you the latest type of activity performed by smartphone users [3].

This solution is expected to help the campus residents to know which parking area is still available in UIN Syarif Hidayatullah.

\section{Related Work}

In previous research [4] applied geofencing as a means of monitoring children by parents by utilizing the GPS contained in the smartphone. The coordinates of the child's location are captured by the GPS and then sent to the server. And when a child enters or leaves a designated area, the parent gets a notification of the child's location immediately.

Another study conducted by [5] monitoring parking in an apartment using RFID technology and Atmega16 microcontroller. Monitoring results will be displayed on the display of available parking slots in the apartment. That way apartment residents can know the condition of the parking area when passing the available display.

Based on these studies, geofencing can be used to track someone by utilizing the existing GPS on their smartphone. That way, the authors try to implement the geofencing in detecting users who parked. Activity recognition is used as a support so that detection is expected to be more accurate because through activity recognition can be known whether the user using the vehicle or not.

\section{Basic Theory}

\subsection{Parking}

Parking is a state of vehicle that does not move and temporarily due to leaved the driver. Parking by the side of the road is generally allowed. But parking in the middle of the highway is prohibited by the law in force in Indonesia. Other circumstances included in the definition of parking are the state of every vehicle that stops at certain places whether expressed by traffic signs or not, and not only to raise and / or decrease people and / or goods [6].

\subsection{Parking Management System}

Parking management system is a system that is able to monitor the condition of the availability of parking location of vehicles in a parking lot and make the information available 
to riders and parking officers in the place. The rider can use the information as a guide to select a parking location. As for the parking attendant, the information is useful for the development of parking areas for the future [7].

\subsection{Geofencing}

According to [8], geofencing is a technique that allows applications to provide information in a more precise way, at the right time and in the right place. This geofencing technique requires 2 main physical components namely the physical area that is limited by digital fences and devices capable of receiving the information provided through the geofencing technique. And when the device passes one of the geofence areas (entering or exiting the area) then there will be alerts or notifications sent to the device.

Geofencing combines the current user's location with the user's distance to the specified location. To mark the desired location requires latitude and longitude of the location. And to adjust the user's distance to that location a radius is required. Then latitude, longitude and radius will create an area of geofences, which the area can be a circle or polygon [9].

There are 3 user conditions that can be known when geofencing is applied :

1. Arriving

Arriving is the condition when the user enters a predetermined location.

2. Dwelling

Dwelling is the condition where the user is still within the specified location.

3. Leaving

Leaving is the condition when the user has been within the specified location then he exited from that location.

\subsection{Activity Recognition}

According to [3], Activity Recognition API is one of the features of Location API owned by Google Play Service. The Activity Recognition API can tell you the latest type of activity performed by smartphone users.

Activities that this API can detects are as follows:

- In Vehichle means the device is in the vehicle

- On Bicycle means the device is on the bike

- On Foot means that the device is on a user who is walking or running

- Running means the device is in the user who is running

- Still means the device does not move at all

- Tilting meaning that the position or angle device changes with gravity significantly

- Unknown meaning the activity can not be detected

- Walking means the device is in the user who is walking

\section{Research Flowchart}

The flow that describes the processes occurring in this study is as follows : 


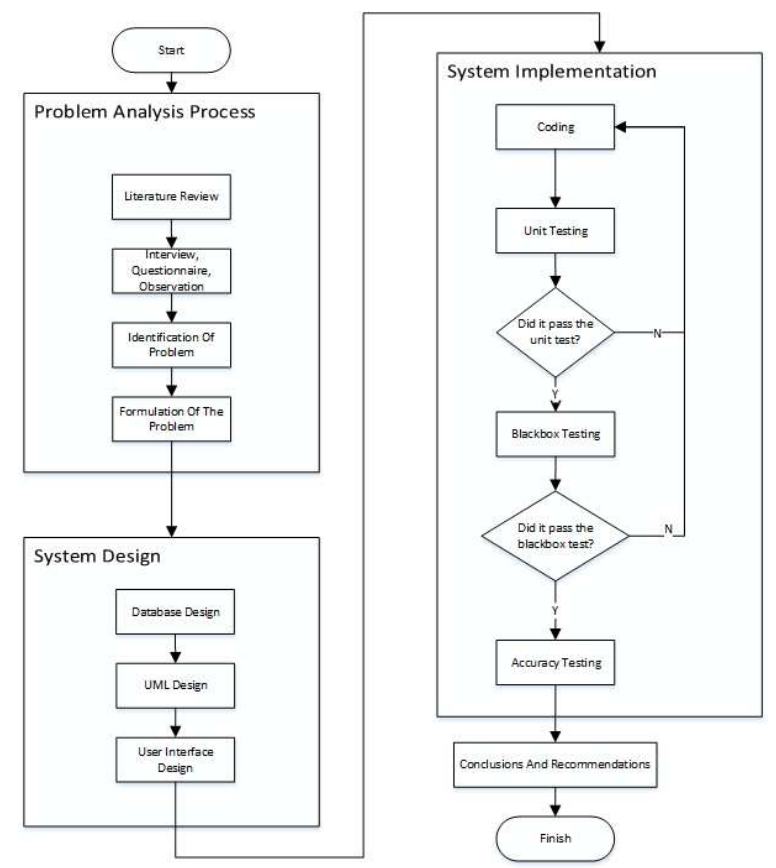

Figure 1. Research Flowchart

\section{Results and Discussion}

\subsection{Proposed System}

The proposed system has 2 levels of geofencing, level 1 is a circular geofencing that surrounds UIN Syarif Hidayatullah. The area is the area where the user will get parking information notification. Furthermore, the geofencing area will be referred to as the notification area. Then level 2 is a polygon-shaped geofencing that signifies as parking area in UIN Syarif Hidayatullah. Furthermore the area will be referred to as the parking area.

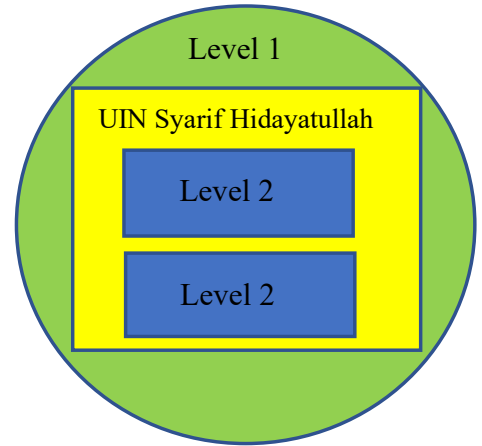

Figure 2. Proposed System Design

Here is the proposed schemes : 
1. User Enters Notification Area

If a user is detected has entered the notification area then the system will send parking information.

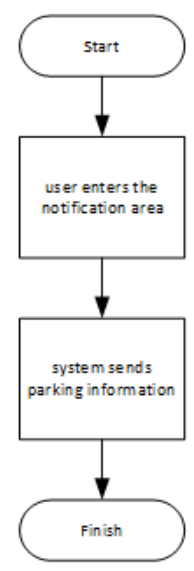

Figure 3. Enter Notification Area

2. User Enters Parking Area

If a user enters the parking area by driving then the system will store the area. If the user re-enter the parking area by walking then the system will note that the user will finish parking.

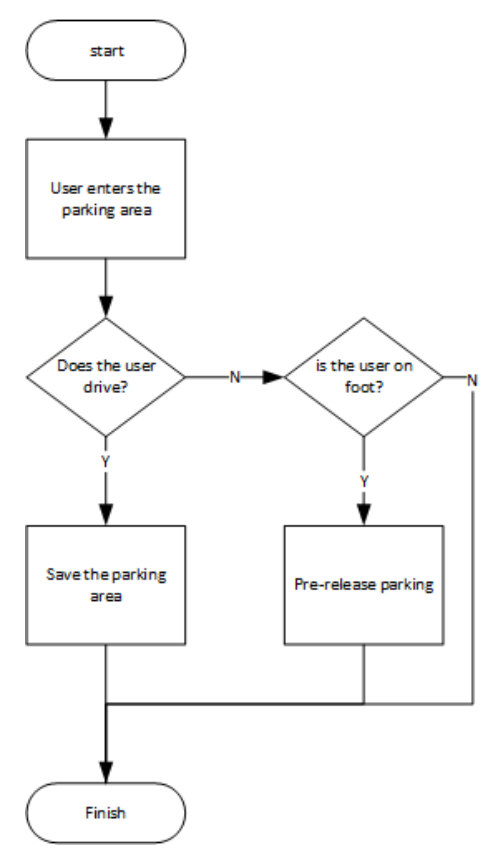

Figure 4. Enter Parking Area 
3. User Exits Parking Area

If user exits the parking area on foot and previously enters by driving then the user is declared to have parked in the area. And if the user exits the parking area by driving and in the condition will be completed parking then the user otherwise completed parking in the area.

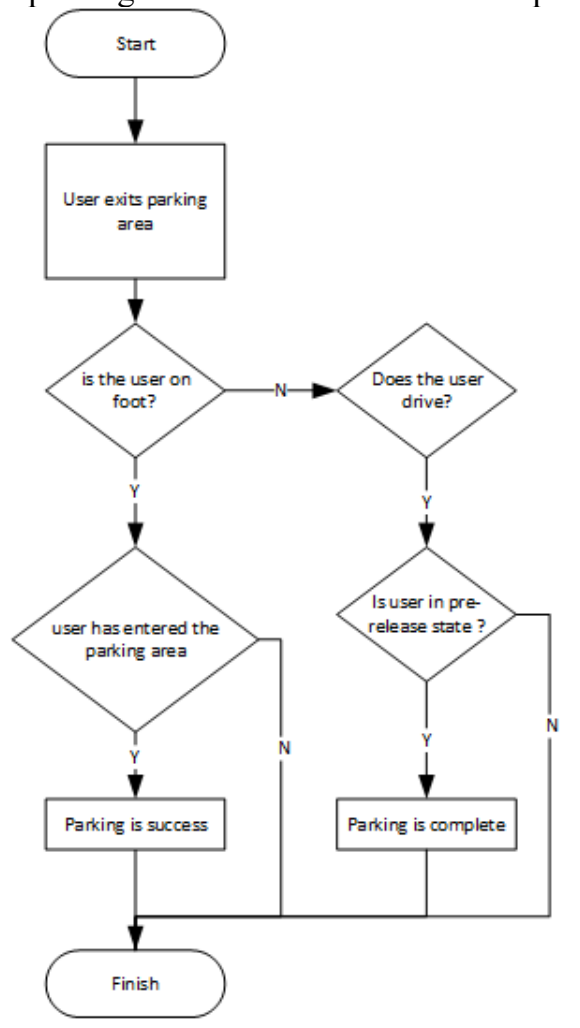

Figure 5. Exit Parking Area

4. User Exits Notification Area

If the user has left the notification area and has been parked on that day then the user is declared to have been out of campus. 


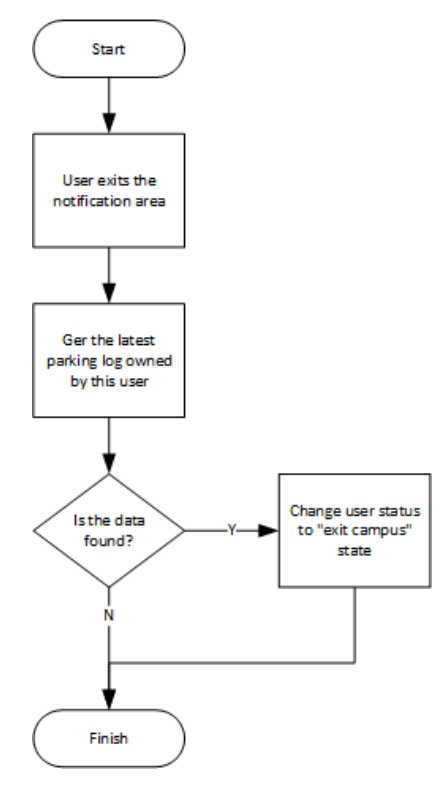

Figure 6. Exit Notification Area

\subsection{Testing Result}

In unit testing, the scope tested is the function used to communicate with the server is correct in sending and receiving data in JSON format. The unit testing results state that all the functions associated with. it pass the test.

In the previous black box testing it is known that there is an unsuccessful test case passed by this design. Test case is located on Parking Entrance in point j. When there are 2 or more passengers in 1 vehicle entering the system should reduce the parking slot based on the number of vehicles parking is 1 . But what happens is the parking slot is reduced according to the passengers in the vehicle.

To handle that, the authors apply the confirmation of the license plate of the vehicle being used. The user will receive a parking confirmation message when the user enters the notification area. With this, then the user with the license plate of the vehicle being used and confirmed it will be declared parking.

And for accuracy testing, Accuracy to be measured in this research is accurate detect geofencing event and activity recognition accuracy in detecting user activity. Geofencing event detected is when the user entered the notification area, exit the notification area and exit the parking area. Meanwhile, user activity is detected when the user is driving a vehicle and walking.

a. Accuracy of Activity Recognition

- Users Driving Vehicle

The results of detection when the user puts the smartphone in a trouser pocket there are 19 of 20 records accordingly with the expected. The percentage of success is $95 \%$. 


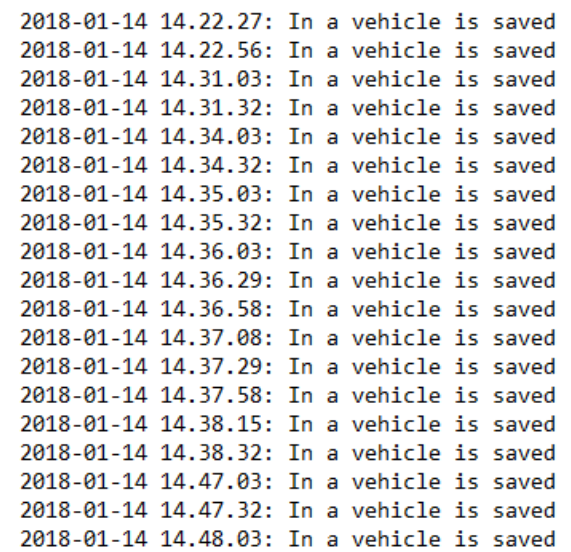

Figure 7. Smartphone Is In Trouser Pocket While User Driving

And the result of detection when the user put the smartphone in the bag there are 15 of 20 results accordingly with the expected. The percentage of success is $75 \%$.

$$
\begin{aligned}
& \text { 2018-01-14 15.31.49: Still is saved } \\
& \text { 2018-01-14 15.32.35: Tilting is saved } \\
& 2018-01-14 \text { 15.32.35: Unknown activity is saved } \\
& 2018-01-14 \text { 15.33.40: Unknown activity is saved } \\
& 2018-01-14 \text { 15.34.30: Unknown activity is saved } \\
& 2018-01-14 \text { 15.38.03: In a vehicle is saved } \\
& 2018-01-14 \text { 15.38.34: In a vehicle is saved } \\
& 2018-01-14 \text { 15.39.02: In a vehicle is saved } \\
& 2018-01-14 \text { 15.39.19: In a vehicle is saved } \\
& 2018-01-14 \text { 15.39.34: In a vehicle is saved } \\
& 2018-01-14 \text { 15.40.05: In a vehicle is saved } \\
& 2018-01-14 \text { 15.40.37: In a vehicle is saved } \\
& 2018-01-14 \text { 15.41.05: In a vehicle is saved } \\
& 2018-01-14 \text { 15.41.36: In a vehicle is saved } \\
& 2018-01-14 \text { 15.45.03: In a vehicle is saved } \\
& 2018-01-14 \text { 15.45.32: In a vehicle is saved } \\
& 2018-01-14 \text { 15.56.00: In a vehicle is saved } \\
& 2018-01-14 \text { 15.56.29: In a vehicle is saved } \\
& 2018-01-14 \text { 16.03.03: In a vehicle is saved } \\
& 2018-01-14 \text { 16.03.32: In a vehicle is saved }
\end{aligned}
$$

Figure 8. Smartphone Is In Bag While User Driving

- Walking User

There are 7 of 20 detection results that do not match the results of detection when the user puts the smartphone in a trouser pocket. The percentage of success is $65 \%$. 


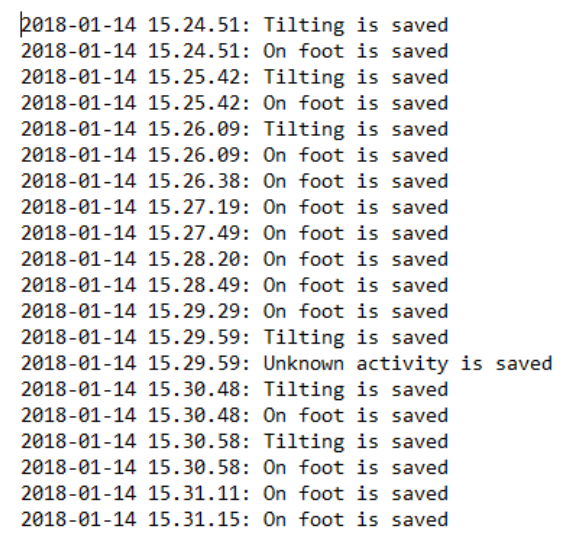

Figure 9. Smartphone is in Trouser Pocket While User Is on Foot

Furthermore there are 5 of 18 incorrect detection results when the user is on foot and using smartphone simultaneously. Then the percentage of success is $72.22 \%$.
2018-01-14 14.57.32: Tilting is saved
2018-01-14 14.57.33: On foot is saved
2018-01-14 14.57.36: On foot is saved
2018-01-14 14.57.43: On foot is saved
2018-01-14 14.57.56: On foot is saved
2018-01-14 14.58.25: On foot is saved
2018-01-14 14.58.47: On foot is saved
2018-01-14 14.59.16: On foot is saved
2018-01-14 14.59.35: On foot is saved
2018-01-14 15.00.00: On foot is saved
2018-01-14 15.00.18: On foot is saved
2018-01-14 15.00.36: On foot is saved
2018-01-14 15.01.12: Tilting is saved
2018-01-14 15.01.12: On foot is saved
2018-01-14 15.02.01: Unknown activity is saved
2018-01-14 15.04.10: Tilting is saved
2018-01-14 15.04.10: Unknown activity is saved
2018-01-14 15.04.40: On foot is saved

Figure 10. User is on Foot and Using Smartphone Simultaneously

b. Accuracy of Geofencing

- Enter Notification Area

Tabel 1. Enter Notification Area Accuracy

\begin{tabular}{ll}
\hline Experiment & Distance (meters) \\
\hline 1 & 10 \\
2 & 8 \\
3 & 15 \\
4 & 20 \\
\hline
\end{tabular}




\begin{tabular}{ll}
\hline 5 & 7 \\
Average distance & 12 \\
\hline
\end{tabular}

The average user gets a notification after entering 12 meters from the geofence boundary. - $\quad$ Exit Notification Area

Tabel 2. Exit Notification Area Accuracy

\begin{tabular}{ll}
\hline Experiment & Distance (meters) \\
\hline 1 & 20 \\
2 & 10 \\
3 & 6 \\
4 & 25 \\
5 & 10 \\
Average distance & 14.2 \\
\hline
\end{tabular}

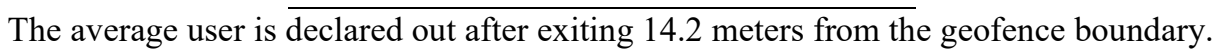
c. Geofence Parking Area

Because the detection of parked users is when the user exits the parking area and the user is in On Foot condition the accuracy tested is accurate when the user exits the parking area. The tested parking area is the parking area in front of the student center building.

Tabel 3. Success Parking Detection Accuracy

\begin{tabular}{ll}
\hline Experiment & Distance (meters) \\
\hline 1 & 10 \\
2 & Not detected \\
3 & 7 \\
4 & 15 \\
5 & 10 \\
6 & 4 \\
7 & 5 \\
\hline
\end{tabular}




\begin{tabular}{ll}
\hline 8 & Not detected \\
9 & Not detected \\
10 & 10 \\
\hline
\end{tabular}

Detected $70 \%$ parking success with the average distance required to be detected is 8.71 meters.

\section{Conclusion}

The application is able to detect the driver who parked without needing sensors at all in the parking area. Then the system has 2 levels of geofence. Level 1 is the circle geofence as the area where the user will get parking info notification. And level 2 is the polygon geofence as the boundary of the parking area which is within the geofence level 1 . This is implemented when the admin determines the boundaries for the parking area.

Accuracy of activity recognition in detecting users who are running and put the smartphone in a pocket reaches $65 \%$. And when the user is running at once using the smartphone reaches $72.22 \%$. For geofencing accuracy, the enter notification area event required 12 meters in average to be detected. And at exit notification area event required 14, 2 meters in average to be detected. And for the detection of parking, parking success detected $70 \%$ with the average distance required is 8,71 meters. Accuracy of the built system depends on the weather and connectivity of the user's smartphone.

Acknowledgements. This paper in conjuction with The 1st International Conference on Islam, Science and Technology (ICONIST 2018) in Malang, East Java.

\section{References}

[1] Badan Pusat Statistik, "Statistik Transportasi Darat 2016," 27 November 2017. [Online]. Available: https://www.bps.go.id/publication/2017/11/27/500b5f875d5762ffb4e7a589/statistiktransportasi-darat-2016.html. [Diakses 2 Desember 2017].

[2] M. D. Dabhi, Geofencing: A Generic Approach to Real Time Location based Tracking System, 2016.

[3] M. Rinne and S. Törmä, Mobile Crowdsensing Of Parking Space Using Geofencing And Activity Recognition, 2014.

[4] R. Segara dan Subari, Sistem Pemantauan Lokasi Anak Menggunakan Metode Geofencing Pada Platform Android, 2017.

[5] F. A. Imbiri, N. Taryana dan D. Nataliana, Implementasi Sistem Perparkiran Otomatis Dengan Menentukan Posisi Parkir Berbasis RFID, 2016.

[6] A. P. Utomo, Analisa Dan Perancangan Sistem Informasi Parkir Di Universitas Muria Kudus, 2013.

[7] J. P. Benson, T. O’Donovan, P. O’Sullivan, U. Roedig dan C. Sreenan, Car-Park Management using Wireless Sensor Networks, 2006. 
[8] A. M. Muriach, Information Provision Improvement With A Geofencing Event-Based System, 2015.

[9] S. Rahate dan M. Shaikh, Geo-fencing Infrastructure : Location Based Service, 2016.

[10] Ismiyati, D. Marlita dan D. Saidah, Pencemaran Udara Akibat Emisi Gas Buang Kendaraan Bermotor, 2014.

[11] S. V. Kamat, News Alert System Using Geofencing, 2014

[12] K. E. Kendall dan J. E. Kendall, Systems Analysis and Design 8th Edition, New Jersey: Prentice Hall, 2011.

[13] M. Masango, F. Moutony, A. Nottinghamz dan J. Mtswenix, Context Aware Mobile Application for Mobile Devices, 2016.

[14] S. Pongpaichet, V. Singh, R. Jain dan A. Pentland, Situation Fencing: Making Geo-Fencing Personal and Dynamic, 2013.

[15] A. Rifai, Sistem Informasi Pemantauan Posisi Kendaraan Dinas Unsri Menggunakan, 2013.

[16] Y. A. Ristanti and L. Sudarmana, Sistem Informasi Pengelolaan Tempat Parkir Rsud Kertosono Nganjuk Berbasis Web, 2016.

[17] D. A. Setyawan, Data Dan Metode Pengumpulan Data Penelitian, 2013.

[18] S. Shinde, A. Patil, S. Chavan, S. Deshmukh dan S. Ingleshwar, IoT based Parking System using Google, 2017.

[19] A. Suyama, Using Geofencing for a Disaster Information System, 2016.

[20] B. Widyantoro, Arini dan H. T. Sukmana, Increasing the Efficiency of Dynamic Programming with Combination of Forward-Backward Method, 2017.

[21] E. Yulianti, Sharia Banking Information : System Analysis And Design, Depok: CEP-CCIT FTUI, 2012. 